\title{
Article \\ Temperature Changes in Composite Materials during Photopolymerization
}

\author{
Leszek Szalewski $^{1} @$, Magdalena Szalewska ${ }^{1,2, *}$, Paweł Jarosz ${ }^{3}$, Michał Woś ${ }^{4}$ and Jolanta Szymańska ${ }^{1}$ \\ 1 Department of Integrated Paediatric Dentistry, Chair of Integrated Dentistry, Medical University of Lublin, \\ 20-093 Lublin, Poland; Leszek.szalewski@umlub.pl (L.S.); Jolanta.szymanska@umlub.pl (J.S.) \\ 2 Doctoral School, Medical University of Lublin, 20-093 Lublin, Poland \\ 3 Engineering Studies Centre, The Institute of Technical Sciences and Aviation, The State School of Higher \\ Education in Chełm, 22-100 Chełm, Poland; pjarosz@pwszchelm.edu.pl \\ 4 Department of Computer Science and Medical Statistics with the Studio of Remote Learning, Medical \\ University of Lublin, 20-093 Lublin, Poland; 49629@student.umlub.pl \\ * Correspondence: 35812@student.umlub.pl
}

check for updates

Citation: Szalewski, L.; Szalewska, M.; Jarosz, P.; Woś, M.; Szymańska, J. Temperature Changes in Composite Materials during Photopolymerization Appl. Sci. 2021, 11, 474. https://doi. org/10.3390/app11020474

Received: 29 November 2020

Accepted: 2 January 2021

Published: 6 January 2021

Publisher's Note: MDPI stays neutral with regard to jurisdictional clai$\mathrm{ms}$ in published maps and institutional affiliations.

Copyright: () 2021 by the authors. Licensee MDPI, Basel, Switzerland. This article is an open access article distributed under the terms and conditions of the Creative Commons Attribution (CC BY) license (https:// creativecommons.org/licenses/by/ $4.0 /)$.

\begin{abstract}
During polymerization, composite materials cause a temperature rise which may lead to irreversible changes in the dental pulp. The mechanical properties of composite materials depend on a number of factors, such as the composition of the material, the type of polymerization unit, the polymerization mode, and the duration of polymerization. The objective of this study was to assess the temperature rise values and flexural strength of composite materials, as obtained using different modes and times of polymerization. A total of six composite materials were used in the study. Samples of each of the materials were cured using seven polymerization protocols. A CMP-401 digital meter (Sonel, Świdnica, Poland), complete with a type K thermocouple (NiCr-Ni), was used to record the temperature increases during the light curing of the resin composites. Temperature rises were recorded beneath the composite disc in an acrylic matrix. The specimens were tested for flexural strength using a Cometech QC-508M2 testing machine. The lowest results for the increased mean temperature were obtained for Fast-Cure $3 \mathrm{~s}\left(39.0^{\circ} \mathrm{C}\right)$, while the highest results were obtained for Fast-Cure $20 \mathrm{~s}\left(45.8^{\circ} \mathrm{C}\right)$. The highest average temperature values for all tested protocols were recorded for the Z550 Filtek material. Mean flexural strengths as measured in each test group were higher than the minimum value for composite materials as per the ISO:4049 standard. In the case of deep caries with a thin layer of dentin separating the filling from pulp, a base layer or a short polymerization duration mode is recommended to protect pulp from thermal injury.
\end{abstract}

Keywords: temperature rise; composites; polymerization; flexural strength

\section{Introduction}

Composite materials are widely used in every dental practice. As the result of many years of technological development and improvements, as well as changes in their composition, composite materials are very durable, while being esthetically pleasing and popular among dentists. At the same time, numerous manufacturers have introduced increasingly advanced units featuring modifying polymerization programs and power adjustments, so as to ensure the best mechanical performance of composite materials. However, many dentists fail to use polymerization units in the correct manner, by focusing mainly on the anatomical representation and the esthetics of fillings. In the survey carried out by Kopperud et al., almost one third of dentists failed to use proper eye protection against blue light while up to $78.3 \%$ of respondents were unaware of the irradiance values of the polymerization lamp they used [1]. Many respondents did not check the quality of the light produced by the polymerization unit. Other studies have shown that preclinical dental students and dentists in their internship years use polymerization lamps in an incorrect manner, not delivering the required amount of energy to the composite layer. 
Following a briefing on the use of polymerization tips, the number of study subjects who failed to deliver the minimum required energy to the filling was significantly reduced [2]. Many dentists do not analyze polymerization unit power and modes before purchasing, study instructions of dental composite polymerization protocols, or obey polymerization procedures. This is an essential element, which can affect the final treatment result.

As materials science advanced, more and more dental practitioners abandoned the use of base layers, even in deep caries; combined with the increased lamp powers and changes in composite material compositions, this might lead to increased temperatures being achieved during polymerization, and leading to pulp damage. The critical value for pulp damage (temperature increased by $5.5^{\circ} \mathrm{C}$ ) was first reported by Zach and Cohen in 1965 on the basis of a study conducted in five adult rhesus macaque monkeys. The authors demonstrated necrosis of $15 \%$ of the tissue as the pulp temperature was increased by $5.5^{\circ} \mathrm{C}$ [3]. However, not all studies confirmed this value as critical for pulp damage. Gross et al. observed no histological changes within the pulp as its temperature increased by $5.5^{\circ} \mathrm{C}$ [4]. In the study by Runnacles et al., a 60 -s exposure led to the highest increase in pulp temperatures, exceeding $5.5^{\circ} \mathrm{C}$ for certain teeth. However, the authors noted that the critical temperature of pulp damage leading to potential necrosis had been determined by testing the teeth of monkeys rather than humans [5]. There are various methods of protecting the pulp against thermal injury: cooling with water during preparation or using liners, such as calcium hydroxide, mineral trioxide aggregate (MTA), or glass-ionomer cements (GIC) [6-8]. Polymerization lamp choice is essential to avoid pulp overheating. On the other hand, the lamps emitting lower levels of energy can disturb the process of polymerization, thus disabling the acquisition of optimal mechanical parameters, including the tensile strength and the flexural strength.

Since the tensile strength of composites is much lower than their compressive strength, and since tensile strength is typically much more affected by internal flaws, this property is likely the most appropriate test of strength. However, it is usually substituted by measurements of flexural strength as a potentially simpler testing method, well-related to tensile failure. Flexure testing is the standard means for the strength testing of dental composites (ISO 4049), and has been shown to correlate with material wear in some studies [9]. Manufacturers keep upgrading their composite materials using different resins or fillers. Sideridou et al. confirmed that the higher the percentage content of the filler, the higher the flexural strength [10]. The mechanical characteristic of composite materials is affected not only by the composition of materials, but also by the polymerization mode [11-15].

The main objective of this study was to assess the temperature rise values as observed for composite materials during polymerization, and to further assess whether different polymerization durations and modes affect the mechanical properties of materials as exemplified by their flexural strength. The null hypothesis was that the different modes and durations of polymerization would have no effect on the rise of the temperature and flexural strength of the composite materials.

\section{Materials and Methods}

\subsection{Composites}

A total of 6 composite materials in A2, Medium Dentin, and Universal shades were used in the study. These included: Essentia: Universal and Medium Dentin (GC Corporation, Tokyo, Japan), GrandioSO, Polofil Supra (VOCO GmbH, Cuxhaven, Germany), Filtek Z550 (3M ESPE, Minneapolis, MN, USA), and Boston (Arkona LFS, Nasutów, Poland). One half of the materials consisted of nano-hybrid materials, while the other half consisted of micro-hybrid materials (Figure 1). The weight content of the filler material in the study group of materials ranged from $76.5 \%$ to $89 \%$. All materials featured resin-based matrices: Bis-GMA, TEGDMA, UDMA (with the exception of GrandioSO), and Bis-EMA (with the exception of Polofil Supra); the materials differed by the addition of resins such as Bis-MEPP (Essentia), PEGDMA (Filtek Z550), and HEMA (Polofil Supra). The detailed compositions of the materials used in the study are given in Table 1. 


\begin{tabular}{|c|c|c|c|c|c|c|}
\hline & \multicolumn{6}{|c|}{ COMPOSITE MATERIALS } \\
\hline & & D-HYBRID G & & MIC & -HYBRID & ROUP \\
\hline & $\begin{array}{c}\text { POLOFIL } \\
\text { SUPRA }\end{array}$ & $\begin{array}{l}\text { ESSENTIA } \\
\text { UNIVERSAL }\end{array}$ & $\begin{array}{l}\text { MEDIUM } \\
\text { DENTIN }\end{array}$ & GRANDIOSO & BOSTON & FILTEK Z550 \\
\hline Fast-cure 3s & $n=3$ & $n=3$ & $n=3$ & $n=3$ & $n=3$ & $n=3$ \\
\hline Fast-cure 5s & $n=3$ & $n=3$ & $n=3$ & $n=3$ & $n=3$ & $n=3$ \\
\hline Fast-cure 10s & $n=3$ & $n=3$ & $n=3$ & $n=3$ & $n=3$ & $n=3$ \\
\hline Fast-cure 20s & $n=3$ & $n=3$ & $n=3$ & $n=3$ & $n=3$ & $n=3$ \\
\hline Pulse-cure 5s & $n=3$ & $n=3$ & $n=3$ & $n=3$ & $n=3$ & $n=3$ \\
\hline Pulse-cure 10s & $n=3$ & $n=3$ & $n=3$ & $n=3$ & $n=3$ & $n=3$ \\
\hline Step-cure 9s & $n=3$ & $n=3$ & $n=3$ & $n=3$ & $n=3$ & $n=3$ \\
\hline
\end{tabular}

Figure 1. The experimental study design and distribution of samples in groups with curing protocol.

Table 1. Characteristics of composite materials used in the study.

\begin{tabular}{|c|c|c|c|c|c|c|c|}
\hline Material & Manufacturer & Shade & Type & $\begin{array}{l}\text { Filler Content \% } \\
\qquad(w / w)\end{array}$ & Filler Type & Particle Size & Matrix \\
\hline Boston & $\begin{array}{l}\text { Arkona LFS, } \\
\text { Nasutów, } \\
\text { Poland }\end{array}$ & A2 & nano-hybrid & $78 \%$ & $\begin{array}{c}\text { barium- } \\
\text { aluminium-silicon } \\
\text { glass, } \\
\text { fumed silica, } \\
\text { titanium dioxide }\end{array}$ & $15 \mathrm{~nm}-2000 \mathrm{~nm}$ & $\begin{array}{c}\text { Bis-GMA, } \\
\text { UDMA, } \\
\text { Bis-EMA, } \\
\text { TEGDMA }\end{array}$ \\
\hline Grandioso & $\begin{array}{l}\text { Voco, } \\
\text { Cuxhaven, } \\
\text { Germany }\end{array}$ & $\mathrm{A} 2$ & nano-hybrid & $89 \%$ & $\begin{array}{l}\text { glass ceramic filler; } \\
\text { silicon dioxide } \\
\text { nanoparticles }\end{array}$ & $\begin{array}{l}60 \% \text { of paticles: } \\
20-40 \mathrm{~nm}\end{array}$ & $\begin{array}{l}\text { Bis-GMA, } \\
\text { Bis-EMA, } \\
\text { TEGDMA }\end{array}$ \\
\hline Filtek Z550 & $\begin{array}{c}\text { 3M ESPE, St } \\
\text { Paul, MN, USA }\end{array}$ & A2 & nano-hybrid & $82 \%$ & $\begin{array}{l}\text { surface modified } \\
\text { zirconia/silica } \\
\text { filler, non- } \\
\text { agglomerated/non- } \\
\text { aggregated } \\
\text { surface-modified } \\
\text { silica particles }\end{array}$ & $20-3000 \mathrm{~nm}$ & $\begin{array}{l}\text { Bis-GMA, } \\
\text { UDMA, } \\
\text { Bis-EMA, } \\
\text { PEGDMA, } \\
\text { TEGDMA }\end{array}$ \\
\hline Essentia & $\begin{array}{l}\text { GC } \\
\text { Corporation, } \\
\text { Tokyo, Japan }\end{array}$ & $\begin{array}{l}\text { Medium } \\
\text { Dentin }\end{array}$ & micro-hybrid & $81 \%$ & $\begin{array}{l}\text { prepolymerized } \\
\text { fillers, barium } \\
\text { glass, fumed silica }\end{array}$ & no data & $\begin{array}{l}\text { Bis-GMA, } \\
\text { UDMA } \\
\text { Bis-MEPP, } \\
\text { Bis-EMA, } \\
\text { TEGDMA }\end{array}$ \\
\hline Essentia & $\begin{array}{l}\text { GC } \\
\text { Corporation, } \\
\text { Tokyo, Japan }\end{array}$ & Universal & micro-hybrid & $81 \%$ & $\begin{array}{l}\text { prepolymerized } \\
\text { fillers, barium } \\
\text { glass, fumed silica }\end{array}$ & no data & $\begin{array}{c}\text { Bis-GMA, } \\
\text { UDMA } \\
\text { Bis-MEPP, } \\
\text { Bis-EMA, } \\
\text { TEGDMA }\end{array}$ \\
\hline Polofil Supra & $\begin{array}{l}\text { Voco, } \\
\text { Cuxhaven, } \\
\text { Germany }\end{array}$ & $\mathrm{A} 2$ & micro-hybrid & $76.50 \%$ & $\begin{array}{l}\text { Sintraglass } \\
\text { multifillers }\end{array}$ & $50-2000 \mathrm{~nm}$ & $\begin{array}{c}\text { Bis-GMA, } \\
\text { UDMA, } \\
\text { TEGDMA, } \\
\text { HEMA }\end{array}$ \\
\hline
\end{tabular}

\subsection{Light Curing Unit}

The composite materials examined were polymerized using a high-powered LED LCU (Mini LED III Supercharged, Acteon Group, Merignac, France). According to the manufacturer's information, polymerization power $2000 \mathrm{~mW} / \mathrm{cm}^{2}$ when a $7.5-\mathrm{mm}$ diameter tip was used. Three samples of each tested material were cured using 7 polymerization protocols: 4 Fast-Cure modes (full power for 3, 5, 10, and $20 \mathrm{~s}$ (double 10-s program), 2 Pulse-Cure modes (5 and 10 shots of 1-s exposures at full power) and 1 Step-Cure mode (soft start with progressive cycle lasting $9 \mathrm{~s}$ ). In this study, the total energy ranged from 
$6 \mathrm{~J} / \mathrm{cm}^{2}$ (Fast-Cure, $3 \mathrm{~s}$ ) to $40 \mathrm{~J} / \mathrm{cm}^{2}$ (Fast-Cure, $20 \mathrm{~s}$ ). Table 2 shows details pertaining to the LED unit and its polymerization modes.

Table 2. Details of the light polymerization unit and its polymerization modes.

\begin{tabular}{|c|c|c|c|c|c|c|c|}
\hline Model & Manufacturer & $\begin{array}{l}\text { Wavelength } \\
\text { Range }\end{array}$ & $\begin{array}{c}\text { Central } \\
\text { Wavelength }\end{array}$ & Intensity & $\begin{array}{l}\text { Fast-Cure } \\
\text { Mode }\end{array}$ & $\begin{array}{l}\text { Pulse-Cure } \\
\text { Mode }\end{array}$ & $\begin{array}{l}\text { Step-Cure } \\
\text { Mode }\end{array}$ \\
\hline \multirow[t]{2}{*}{$\begin{array}{l}\text { MINI LED III } \\
\text { Supercharged }\end{array}$} & \multirow[t]{2}{*}{$\begin{array}{c}\text { Acteon Group } \\
\text { (Merignac, } \\
\text { France) }\end{array}$} & \multirow[t]{2}{*}{$420-480 \mathrm{~nm}$} & \multirow[t]{2}{*}{$455-465 \mathrm{~nm}$} & \multirow[t]{2}{*}{$\begin{array}{c}2000 \mathrm{~mW} / \mathrm{cm}^{2} \\
\pm 10 \% \text { for an } \\
\text { active fiber } \\
\text { diameter of } \\
7.5 \mathrm{~mm}\end{array}$} & $\begin{array}{l}\text { Full power for } \\
3 / 5 / 10 \mathrm{~s}\end{array}$ & $\begin{array}{l}5 / 10 \text { shots of } 1 \mathrm{~s} \\
\text { (full power with } \\
\text { emission of } 5 / 10 \\
\text { successive one } \\
\text { second flashes } \\
\text { with a rest of } \\
\text { period of } 250 \mathrm{~ms} \\
\text { between } \\
\text { each flash) }\end{array}$ & $\begin{array}{l}6 \mathrm{~s} \\
\text { progressively } \\
\text { and } 3 \mathrm{~s} \text { at } \\
\text { full power }\end{array}$ \\
\hline & & & & & $\begin{array}{l}\text { Total energy: } \\
3 \mathrm{~s}-6 \mathrm{~J} / \mathrm{cm}^{2} \\
5 \mathrm{~s}-10 \mathrm{~J} / \mathrm{cm}^{2} \\
10 \mathrm{~s}-20 \mathrm{~J} / \mathrm{cm}^{2} \\
20 \mathrm{~s}-40 \mathrm{~J} / \mathrm{cm}^{2}\end{array}$ & $\begin{array}{c}\text { Total energy: } \\
5 \text { shots }-10 \mathrm{~J} / \mathrm{cm}^{2} \\
10 \text { shots- } \\
20 \mathrm{~J} / \mathrm{cm}^{2}\end{array}$ & $\begin{array}{c}\text { Total energy: } \\
12 \mathrm{~J} / \mathrm{cm}^{2}\end{array}$ \\
\hline
\end{tabular}

\subsection{Temperature Measurement}

One hundred and twenty-six specimens were prepared overall, with a total of twentyone specimens for each composite material, whereby three specimens $(n=3)$ were polymerized using one of the seven curing modes. All specimens were prepared in an acrylic resin matrix of the same shape $(7.5 \mathrm{~mm}$ in diameter, $2 \mathrm{~mm}$ deep). The tip of the light curing unit touched the composite resin through a protective cover to simulate the situation of filling a tooth within the oral cavity. The scheme of the test stand is shown in Figure 2.

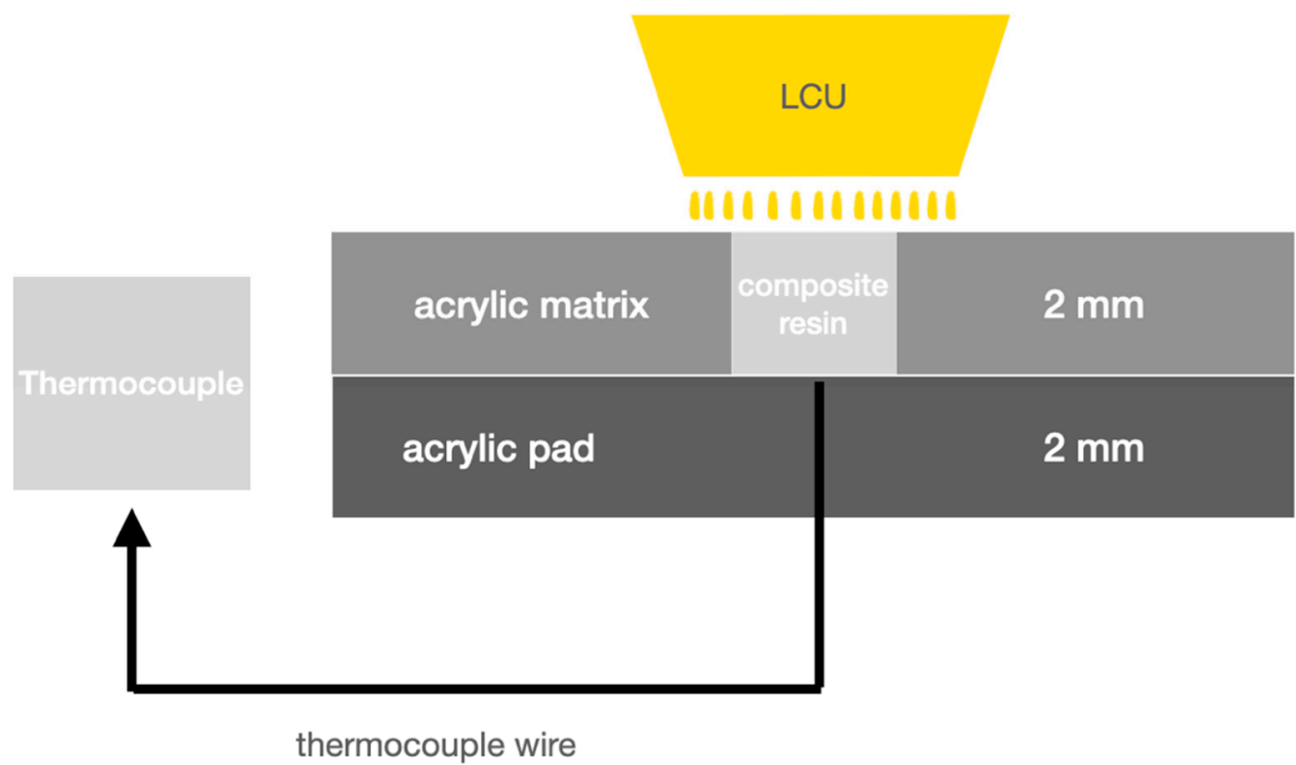

Figure 2. Scheme of the test stand for measuring temperature changes.

All measurements were taken in a temperature-controlled room at a constant temperature of $29 \pm 1{ }^{\circ} \mathrm{C}$. A CMP-401 digital meter (Sonel, Świdnica, Poland) complete with a type $\mathrm{K}$ thermocouple (NiCr-Ni) was used to record the temperature increases during the light curing of the resin composites. Temperature rises were recorded beneath the composite disc in the acrylic matrix. Two measurements were recorded during each session, namely the initial temperature and then the maximum temperature achieved in the time of polymerization. The obtained results were analyzed statistically. 


\subsection{Flexural Strength Test}

Seventy specimens were prepared for flexural strength test according to the ISO standard 4049:201012, using the Boston (Arkona LFS, Nasutów, Poland) composite resin (shade A2). Rectangular specimens $(25 \mathrm{~mm} \times 2 \mathrm{~mm} \times 2 \mathrm{~mm}$ ) were produced using a steel mold and placed on a microscope slide to achieve a flat surface. Subsequently, one portion of composite resin was condensed with a dental plugger and flattened by being pressed using another microscope slide. The composite material was then polymerized across a layer of polyethylene film in order to eliminate oxygen inhibition at the surface. Samples were polymerized using a high-powered LED LCU (Mini LED III Supercharged, Acteon Group, Merignac, France) using 7 different modes; the same as for the temperature measurement tests. Ten specimens were used for each mode and duration. Each rectangular sample was polymerized at 4 points. After polymerization, the specimens were released from the mold. Next, the specimens were examined for the presence of air bubbles and defective specimens were excluded from the study. Specimens were then immersed in distilled water at a temperature of $37^{\circ} \mathrm{C}$ for $24 \mathrm{~h}$. Next, the specimens were tested for flexural strength using the Cometech QC-508M2 testing machine (Cometech Testing Machines Co., Taichung City, Taiwan) with the opening width of $20 \mathrm{~mm}$, initial gripping force of $1 \mathrm{~N}$ and the crosshead speed of $0.75 \mathrm{~mm} / \mathrm{min}$. The specimens were measured to an accuracy of 0.01 $\mathrm{mm}$ before the test. The test end was marked by the specimen being crushed.

Flexural strength was calculated using the following equation:

$$
\mathrm{S}=3 \mathrm{FL} /\left(2 \mathrm{BH}^{2}\right)
$$

where $\mathrm{F}$ is the maximum load in Newtons exerted on the specimens, $\mathrm{L}$ is the distance (20 $\mathrm{mm}$ ) between the supports, accurate to $\pm 0.01 \mathrm{~mm}$, B is the width $(2 \mathrm{~mm} \pm 0.01 \mathrm{~mm})$ of the specimens measured immediately prior to testing and $\mathrm{H}$ is the height $(2 \mathrm{~mm} \pm 0.01 \mathrm{~mm})$ of the specimens measured immediately prior to testing.

\subsection{Statistical Analysis}

The mean maximum temperatures at the assigned measurement sites and flexural strength were analyzed using ANOVA and Shapiro-Wilk tests. The analyses were conducted using Statistica software version 13 (Statsoft, Warszawa, Poland) at the significance level of 0.05 .

\section{Results}

The specific values of the average temperatures before and during the test along with the standard deviations are summarized in Table 3.

The statistical analysis (Shapiro-Wilk test for normality) showed a significance level for Fast-cure $3 \mathrm{~s}(\mathrm{~W}=0.96364, p$-value $=0.6732)$, Fast-cure $5 \mathrm{~s}(\mathrm{~W}=0.95208, p$-value $=0.4585)$, Fast-cure $10 \mathrm{~s}(\mathrm{~W}=0.96143, p$-value $=0.6294)$, Fast-cure $20 \mathrm{~s}(\mathrm{~W}=0.97366, p$-value $=0.863)$, Pulse-cure $5 \mathrm{~s}(\mathrm{~W}=0.96143, p$-value $=0.6294)$, Pulse-Cure $10 \mathrm{~s}(\mathrm{~W}=0.95192, p$-value $=0.4559)$, and Step-Cure $9 \mathrm{~s}(\mathrm{~W}=0.9568, p$-value $=0.5412)$. We cannot reject normality in the test groups. The lowest average results were obtained for Fast-Cure $3 \mathrm{~s}\left(39.0^{\circ} \mathrm{C} \pm \mathrm{SD} 2.7\right)$, while the highest average results were obtained for Fast-Cure $20 \mathrm{~s}\left(45.8^{\circ} \mathrm{C} \pm \mathrm{SD} 2.0\right)$. The temperature increase was the lowest for $3 \mathrm{~s}$ of continuous polymerization, amounting to $10.1{ }^{\circ} \mathrm{C}$, while being the highest for $20 \mathrm{~s}$ of continuous polymerization $\left(16.3^{\circ} \mathrm{C}\right)$. The highest average temperature values for all tested protocols were recorded for the Z550 Filtek material. The variance estimated based on the variability within the group showed a statistical significance for polymerization time $(\mathrm{F}=1.4778)$ and for the type of filler $(\mathrm{F}=2.2404)$. (Table 4). 
Table 3. Mean temperature values and standard deviations (SD) for the composite materials and light curing modes evaluated.

\begin{tabular}{|c|c|c|c|c|c|c|c|c|c|c|c|c|c|c|}
\hline & \multicolumn{2}{|c|}{ Fast-Cure $3 \mathrm{~s}$} & \multicolumn{2}{|c|}{ Fast-Cure $5 \mathrm{~s}$} & \multicolumn{2}{|c|}{ Fast-Cure $10 \mathrm{~s}$} & \multicolumn{2}{|c|}{$\begin{array}{c}\text { Fast-Cure } 20 \text { s }(2 \times 10 \\
\text { s) }\end{array}$} & \multicolumn{2}{|c|}{ Pulse-Cure $5 \mathrm{~s}$} & \multicolumn{2}{|c|}{ Pulse-Cure $10 \mathrm{~s}$} & \multicolumn{2}{|c|}{ Step-Cure $9 \mathrm{~s}$} \\
\hline & T0 & T1 & T0 & T1 & T0 & T1 & T0 & T1 & T0 & T1 & T0 & T1 & T0 & T1 \\
\hline BOSTON & $28.4(0.3)$ & $36.0(0.4)$ & $28.3(0.4)$ & $41.5(0.6)$ & $28.8(0.2)$ & $45.7(0.9)$ & $28.9(0.3)$ & $46.7(2.1)$ & $29.3(0.1)$ & $42.4(1.8)$ & $29.1(0.2)$ & $44.8(1.0)$ & $29.2(0.1)$ & $45.7(2.7)$ \\
\hline FILTEK Z550 & $29.5(0.1)$ & $41.6(1.6)$ & $29.7(0.3)$ & $48.0(2.5)$ & $29.8(0.1)$ & $47.3(1.4)$ & $29.9(0.1)$ & $47.7(1.8)$ & $29.0(0.1)$ & $44.5(1.3)$ & $29.8(0.1)$ & $47.4(1.8)$ & $29.1(0.8)$ & $47.2(1.1)$ \\
\hline $\begin{array}{c}\text { ESSENTIA } \\
\text { MEDIUM DENTIN }\end{array}$ & $29.0(0.1)$ & $36.3(1.0)$ & $29.6(0.2)$ & $42.8(1.6)$ & $29.7(0.1)$ & $45.2(1.3)$ & $30(0.5)$ & $45.3(0.7)$ & $29.9(0.1)$ & $43.9(2.1)$ & $29.9(0.2)$ & $43.3(0.6)$ & $29.3(0.3)$ & $46.1(1.8)$ \\
\hline $\begin{array}{c}\text { ESSENTIA } \\
\text { UNIVERSAL }\end{array}$ & $29.0(0.2)$ & $41.2(0.3)$ & $28.6(0.1)$ & $42.6(2.1)$ & $28.7(0.2)$ & $43.7(0.1)$ & $29.3(0.3)$ & $46.5(0.7)$ & $29.5(0.1)$ & $43.3(0.6)$ & $29.5(0.3)$ & $44.6(1.8)$ & $29.6(0.2)$ & $43.8(2.6)$ \\
\hline POLOFIL SUPRA & $28.5(0.2)$ & $41.1(0.3)$ & $29.0(0.2)$ & $46(1.5)$ & $29.2(0.2)$ & $47.3(0.4)$ & $29.5(0.1)$ & $46.7(1.1)$ & $29.4(0.2)$ & $44.6(2.4)$ & $29.4(0.1)$ & $45.9(0.8)$ & $29.6(0.2)$ & $45.5(0.5)$ \\
\hline TOTAL & $28.8(0.45)$ & $39.0(2.7)^{\mathrm{a}}$ & $28.9(0.6)$ & $43.6(3.0)^{a}$ & $29.2(0.5)$ & $45.0(2.3)^{b}$ & $29.4(0.4)$ & $45.8(2.0)^{\mathrm{b}}$ & $29.6(0.2)$ & $43.3(1.7)^{b}$ & $29.6(0.3)$ & $45.0(1.9)^{\mathrm{b}}$ & $29.4(0.4)$ & $45.2(1.9)^{b}$ \\
\hline
\end{tabular}

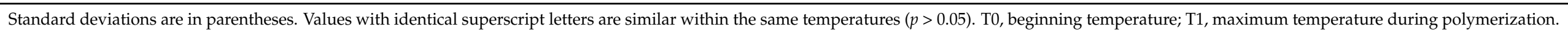


Table 4. Multiple factor ANOVA test for the time of polymerization and the type of filler.

\begin{tabular}{llllll}
\hline Response: $\mathbf{d t}$ & & & & & \\
\hline & Df & Sum Sq & Mean Sq & F value & $\operatorname{Pr}(>\mathrm{F})$ \\
Filler & 1 & 52.00 & 52.001 & 2.2404 & 0.1371 \\
Polymerization & 6 & 66.54 & 11.090 & 1.4778 & 0.3237 \\
time & 118 & 2738.89 & 23.211 & \\
Residuals & & & & \\
\hline
\end{tabular}

Mean flexural strengths as measured in each test group were higher than the minimum value for composite materials as per the ISO:4049 standard, i.e., $80 \mathrm{MPa}$ (Figure 3).

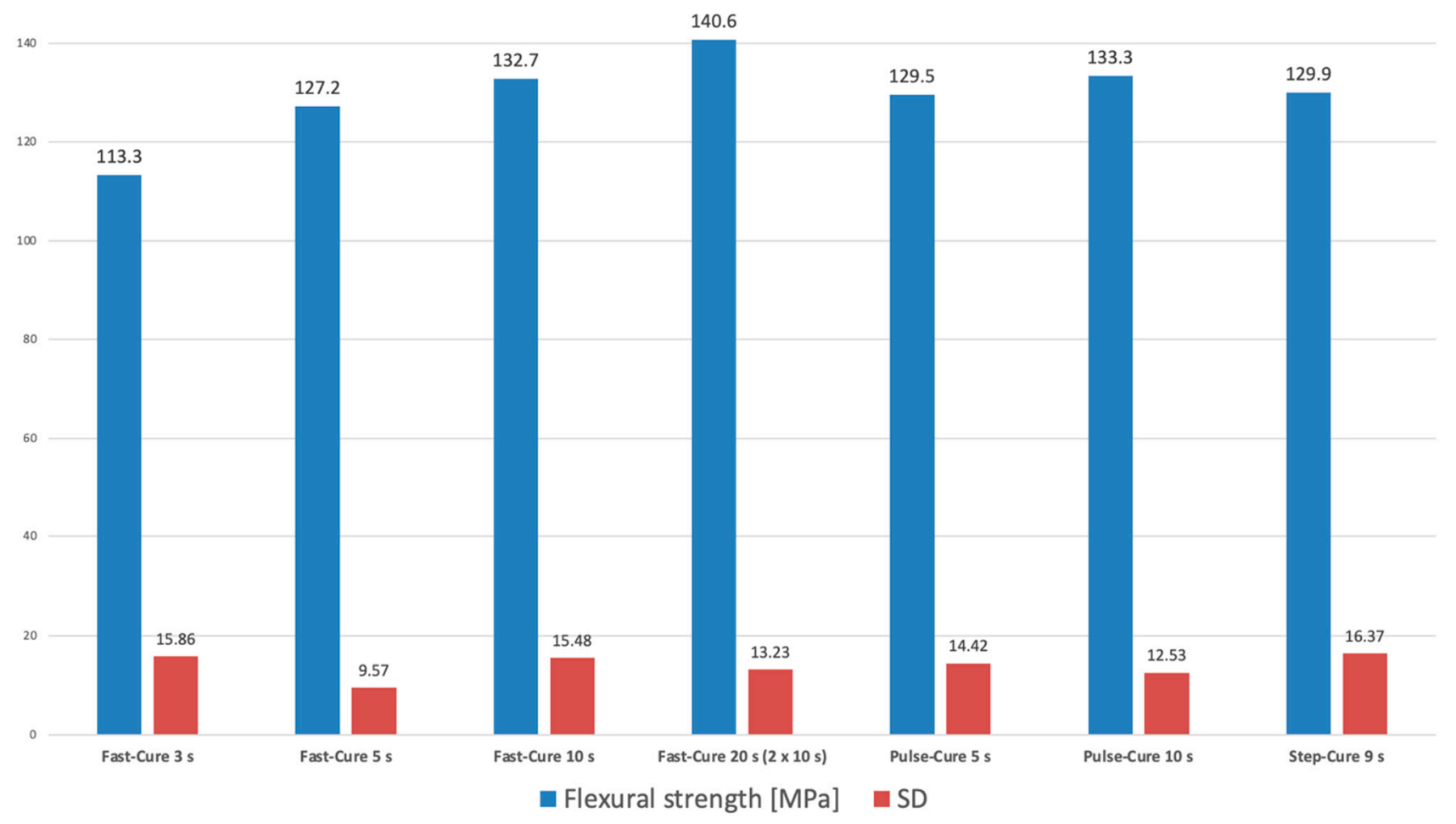

Figure 3. Mean values of flexural strength $(\mathrm{MPa})$ and standard deviations.

The statistical analysis (Shapiro-Wilk test for normality) showed a significance level for Fast-cure $3 \mathrm{~s}(\mathrm{~W}=0.97125, p=0.90220)$, Fast-cure $5 \mathrm{~s}(\mathrm{~W}=0.97324 p=0.91020)$, Fast-cure $10 \mathrm{~s}(\mathrm{~W}=0.95863, p=0.86159)$, Fast-cure $20 \mathrm{~s}(\mathrm{~W}=0.95945, p=0.90257)$, Pulse-cure $5 \mathrm{~s}$ $(\mathrm{W}=0.99865, p=0.97432)$, Pulse-cure $10 \mathrm{~s}(\mathrm{~W}=0.96699, p=0.91351)$, and Step-cure $9 \mathrm{~s}$ $(\mathrm{W}=0.95980, p=0.90619)$. We cannot reject normality in the test groups. The lowest flexural strength was measured for the Fast-Cure $3 \mathrm{~s}$ protocol, while the highest flexural strength was measured for the Fast-Cure $20 \mathrm{~s}$ protocol, the differences being statistically significant $(p=0.02060)$.

\section{Discussion}

The research results show that the change of the polymerization time has a great impact on the mechanical properties, such as flexural strength. Furthermore, the increase of the material temperature was influenced by the polymerization time. Hence, the null hypothesis was rejected. The results demonstrated that in our study the average temperature 
as measured for all test materials did not exceed $42.0^{\circ} \mathrm{C}$ for Fast-Cure $3 \mathrm{~s}$ mode. This value was exceeded for the remaining polymerization modes, reaching a maximum value of $45.8^{\circ} \mathrm{C}$ for Fast-Cure $20 \mathrm{~s}$. This value is particularly important for deep cavities with only a thin layer of dentin separating the composite material from the pulp. High temperatures can cause irreversible damage to pulp tissue, and therefore require endodontic treatment.

The study of Khaksaran et al. measured the temperatures following polymerization of bonding systems (N Bond, G-Bond, OptiBond XTR, Clearfil SE, Adper Single Bond 2 and $\mathrm{V}$ Bond) on pre-prepared dentin discs obtained from human third molars. The study environment temperature of experiments was $37^{\circ} \mathrm{C}$. The irradiation time was $20 \mathrm{~s}$, and the minimum and maximum temperature rise growth in all subgroups was $1.7^{\circ} \mathrm{C}$ and $2.8^{\circ} \mathrm{C}$, respectively. In the case of the $20 \mathrm{~s}$ polymerization protocol, no dangerous rise in temperature $\left(5.5^{\circ} \mathrm{C}\right)$ was obtained for either of the bonding systems tested [16]. Our research findings revealed that the maximum temperature increase for the $20 \mathrm{~s}$ mode (Fast-cure, $2 \times 10 \mathrm{~s}$ ) was $17.8^{\circ} \mathrm{C}$, for the Filtek Z550 material, with the lowest of $7.25^{\circ} \mathrm{C}$ for the Essentia Medium Dentin $3 \mathrm{~s}$ mode. In our study the initial temperature was maintained at $29 \pm 1{ }^{\circ} \mathrm{C}$. The critical pulp temperature values were not exceeded in the case of Fastcure 3 s mode. Jo et al., in their study, performed on 30 extracted human molars with class I cavities filled using a nano-hybrid material (Filtek Bulk Fill Posterior Restorative (BFP, 3M ESPE)), found the maximum temperature increase during polymerization at $0.625 \mathrm{~mm}$ apically from the top and center of the defect. On the basis of their results, the authors concluded that replacing pulsed or soft start modes with continuous irradiation might reduce the risk of damage to the pulp [17]. The authors' research does not confirm this thesis. For the $5 \mathrm{~s}$ modes (Fast-cure and Pulse-cure) and $10 \mathrm{~s}$ (Fast-cure, Pulse-cure and Step-cure $9 \mathrm{~s}$ ) temperature rises were similar: $\pm 14{ }^{\circ} \mathrm{C}\left(5 \mathrm{~s}\right.$ modes) and $\pm 15.5{ }^{\circ} \mathrm{C}$ (10 s modes). Another study (Braga et al.) compared the rise in the temperature during polymerization of two materials (SDR, Dentsply and AURA, SDI) polymerized using two lamps (Bluephase G2, Ivoclar Vivadent, and VALO Cordless, Ultradent) in the standard output power mode. An increase of $6{ }^{\circ} \mathrm{C}$ was observed for the Bluephase G2 lamp, as compared to $4{ }^{\circ} \mathrm{C}$ for the VALO Cordless lamp for the light curing adhesive system $(20 \mathrm{~s}$ mode without microcirculation) [18]. Our study demonstrated that for fast-cure $20 \mathrm{~s}$ mode $(2 \times 10 \mathrm{~s})$ the highest temperature increase was $17.8^{\circ} \mathrm{C}$, in the case of Filtek Z550 material. There was no simulated pulpal microcirculation. On the other hand, Kim et al. measured the temperature rise in class I cavities in third molars in the course of layered filling with a composite material (Filtek Z250, Shade A2, lot N506344, 3M ESPE, St. Paul, MN, USA). The temperature was measured for $110 \mathrm{~s}$ using eight thermocouples. The authors demonstrated that the rise in the temperature within the cavity was significantly higher during polymerization of the first layer of material $\left(59.8^{\circ} \mathrm{C}\right)$ compared to the next layer $\left(58.5^{\circ} \mathrm{C}\right)$ [19]. The authors' findings do not demonstrate such a temperature increase, even in $20 \mathrm{~s}$ mode. This might support the idea of shorter polymerization durations being used for the deepest layers of composite fillings. In a subsequent examination of six composites (Admira, Filtek P60, Premise, Tetric Flow, Tetric Ceram, and Filtek Z250) polymerized using different modes (standard (10 s, full power), pulsed (10 consecutive one-second exposures at full power) or soft start (progressive cycle lasting $20 \mathrm{~s}$ )), with a type L thermocouple being used for temperature measurements, higher temperature rises were observed for soft start exposures (in the case of Admira and Tetric Flow materials). The lowest rise in temperature was observed for the Premise material irradiated using the pulsed protocol. None of the exposure protocols tested resulted in temperature being raised to the critical value [20]. In the authors' research the lowest temperature rise was observed for Essentia Medium Dentin and Fast-cure $3 \mathrm{~s}$ mode $\left(7.25^{\circ} \mathrm{C}\right)$. No significant differences in temperature rise were found between modes with similar durations. In another study, three polymerization units were compared, one halogen lamp (QTH LCU XL2500 (3M/ESPE), two LED lamps (Freelight LED LCU (3M/ESPE), and Ultrablue (DMC Equipamentos LTDA) on a one composite material (Filtek Z250, 3M/ESPE). Five types of photoactivation modes were used: $20 \mathrm{~s}$ with each of the three light curing units according to the manufacturer's instructions, $50 \mathrm{~s}$ with 
the Freelight LED lamp, and $30 \mathrm{~s}$ with the Ultrablue IS lamp. The authors demonstrated that for photoactivation times as per the manufacturer's recommendations, both LED lamps produced a lower temperature rise than the QTH lamp (average temperature rise values in degrees Celsius: Ultrablue LED 1.13 (0.05), Freelight LED 1.05 (0.16) vs. QTH XL 2500 $1.57(0.13))$. However, the authors stressed that the choice of the type of the polymerization lamp affected the average temperature rises [21]. However, other studies did not confirm the reports suggesting that LED lamps generated lower temperature rise values. A study using 96 fragments of bovine teeth revealed that higher temperatures were obtained during polymerization of composite materials using a LED lamp as compared to halogen lamps. However, the temperature increase was above $5.5^{\circ} \mathrm{C}$ for both tested lamps, which could be considered as a critical value [22]. The authors' study demonstrated that the temperature rise was lower than the critical temperature value only for the $3 \mathrm{~s}$ Fast-cure mode. For other modes and durations, the final temperature was higher than the critical temperature value. Santini et al. used two LED lamps (Bluephase, Elipar Freelight 2) and a halogen lamp (Prismatics). The authors demonstrated that for all light curing units, the exposure of the bonding system resulted in temperature rises being significantly higher than those observed for the exposure of composite materials. However, higher temperatures were achieved during the polymerization of bonding systems and resin-based composite materials using both LED lamps compared to the halogen lamp [23]. Bagis et al. demonstrated that for the output values of all units tested (halogen, plasma, LED), the temperature rise exceeded $5.5^{\circ} \mathrm{C}$; and the temperature rose along with increasing polymerization duration [24].

Type of polymerization unit and irradiation modes also affect the mechanical properties of composite materials. One such parameter is flexural strength. The study by Pieniak et al. revealed no impact on flexural strength when a LED lamp was used instead of a halogen lamp to polymerize the Filtek Silorane (3M ESPE) and Herculite XRV (Kerr) composite materials. However, a rise in flexural strength was demonstrated as being due to increased polymerization duration when using a halogen lamp for polymerization of Filtek Silorane. In the study, lower values of flexural strength were obtained for methacrylate resin-based materials (Gradia Direct Anterior and Gradia Direct Posterior, GC Japan) [25]. According to our findings, polymerization time affected flexural strength, not the mode of light curing. Another study revealed higher flexural strength values for hybrid composite materials compared to nanofill resins. The authors used two composite materials with different filler types, namely the Filtek P60 3M ESPE (hybrid) and Filtek Supreme 3M ESPE (nanofill) [26]. Another study using the Z250 (3M ESPE) composite and the Scotchbond Multi-purpose Plus (3M ESPE) bonding system revealed that the photoactivation method applied had no impact on the performance of the composite material (including flexural strength), regardless of the material storage medium (water vs. ethanol) [27]. The Filtek Z250 (3M ESPE) and Heliomolar (Ivoclar Vivadent) composite materials were tested by Calheiros et al. at polymerization energy doses of $6-24 \mathrm{~J} / \mathrm{cm}^{2}$. A rise in flexural strength was observed for increasing energy doses for the Filtek Z250 material, whereas no changes in mechanical properties were observed for the Heliomolar composite [28]. The authors' results confirmed the hypothesis that the polymerization energy dose influences the flexural strength value.

All in vitro studies have their limitations. The baseline test stand temperature in our study was lower than the temperature within the cavity. However, even starting at lower temperatures, some values exceeded the limit value of $42{ }^{\circ} \mathrm{C}$. The effects of thermal absorption within the dentin tissue, potentially leading to lower values during polymerization, were not taken into account in the tests. In addition, in the case of deep cavities, it is not always possible to reach the composite layer with the polymerization tip, and the energy dose, leading to the rise in the temperature, is reduced with increasing distance. The effect of the bonding system on the temperature rise was not taken into account in our study, so as to maintain constant conditions for all materials for which different bonding systems are recommended by their manufacturers. 
Subsequent studies should be based on the model of human teeth, in which natural heat dissipation in hard tissues will be obtained. In addition, it would be advisable to examine how liners and their thickness affect the transmission of thermal energy to the tooth pulp. Such studies would allow obtaining a safe clinical procedure for the treatment of deep carious lesions.

\section{Conclusions}

Based on the results of this in vitro study, the following conclusions were drawn:

1. Short polymerization durations lead to lower temperature rise values, while extended polymerization durations increase the values to a critical temperature for pulp damage.

2. The temperature rise was determined by polymerization durations rather than by the exposure mode used.

3. The temperature rise varied according to the materials used.

4. Sufficient flexural strength was obtained for all polymerization modes.

In the case of deep caries with a thin layer of dentin separating the filling from pulp, a base layer or a short duration polymerization mode is recommended to protect pulp from thermal injury during polymerization of the composite materials.

Author Contributions: Conceptualization, L.S., M.S. and J.S.; methodology, L.S. and P.J.; software, M.W.; formal analysis, M.S. and J.S.; investigation, L.S. and P.J.; resources, J.S.; data curation, P.J. and M.W.; writing—original draft preparation, L.S. and M.S.; writing-review and editing, P.J., M.W. and J.S.; visualization, L.S. and M.W.; supervision, J.S.; project administration, M.S. All authors have read and agreed to the published version of the manuscript.

Funding: This research received no external funding.

Data Availability Statement: The data that support the findings of this study are available from the corresponding author, [MS], upon reasonable request.

Conflicts of Interest: The authors declare no conflict of interest.

\section{References}

1. Kopperud, S.E.; Rukke, H.V.; Kopperud, H.M.; Bruzell, E.M. Light curing procedures-performance, knowledge level and safety awareness among dentists. J. Dent. 2017, 58, 67-73. [CrossRef]

2. Suliman, A.A.; Abdo, A.A.; Elmasmari, H.A. Training and experience effect on light-curing efficiency by dental practitioners: Training and experience effect on light-curing. J. Dent. Educ. 2020, 84, 652-659. [CrossRef] [PubMed]

3. Zach, L.; Cohen, G. Pulp response to externally applied heat. Oral Surg. Oral Med. Oral Pathol. 1965, 19, 515-530. [CrossRef]

4. Gross, D.J.; Dávila-Sánchez, A.; Runnacles, P.; Zarpellon, D.C.; Kiratcz, F.; Campagnoli, E.B.; Alegría-Acevedo, L.F.; Coelho, U.; Rueggeberg, F.A.; Arrais, C.A.G. In vivo temperature rise and acute inflammatory response in anesthetized human pulp tissue of premolars having Class V preparations after exposure to Polywave ${ }^{\circledR}$ LED light curing units. Dent. Mater. 2020, 36, $1201-1213$. [CrossRef] [PubMed]

5. Runnacles, P.; Arrais, C.A.G.; Pochapski, M.T.; dos Santos, F.A.; Coelho, U.; Gomes, J.C.; De Goes, M.F.; Gomes, O.M.M.; Rueggeberg, F.A. In vivo temperature rise in anesthetized human pulp during exposure to a polywave LED light curing unit. Dent. Mater. 2015, 31, 505-513. [CrossRef] [PubMed]

6. Garrocho-Rangel, A.; Esparza-Villalpando, V.; Pozos-Guillen, A. Outcomes of direct pulp capping in vital primary teeth with cariously and non-cariously exposed pulp: A systematic review. Int. J. Paediatr. Dent. 2020, 30, 536-546. [CrossRef] [PubMed]

7. Cervino, G.; Laino, L.; D’Amico, C.; Russo, D.; Nucci, L.; Amoroso, G.; Gorassini, F.; Tepedino, M.; Terranova, A.; Gambino, D.; et al. Mineral Trioxide Aggregate Applications in Endodontics: A Review. Eur. J. Dent. 2020, 14, 683-691. [CrossRef]

8. Bjørndal, L.; Simon, S.; Tomson, P.L.; Duncan, H.F. Management of deep caries and the exposed pulp. Int. Endod. J. 2019, 52, 949-973. [CrossRef]

9. Peutzfeldt, A.; Asmussen, E. Modulus of resilience as predictor for clinical wear of restorative resins. Dent. Mater. 1992, 8, 146-148. [CrossRef]

10. Sideridou, I.D.; Karabela, M.M.; Vouvoudi, E.C. Physical properties of current dental nanohybrid and nanofill light-cured resin composites. Dent. Mater. 2011, 27, 598-607. [CrossRef]

11. Ilie, N.; Stark, K. Effect of different curing protocols on the mechanical properties of low-viscosity bulk-fill composites. Clin. Oral Investig. 2015, 19, 271-279. [CrossRef] [PubMed] 
12. Aljosa, I.; Tijana, L.; Larisa, B.; Marko, V. Influence of Light-curing Mode on the Mechanical Properties of Dental Resin Nanocomposites. Procedia Eng. 2014, 69, 921-930. [CrossRef]

13. Catelan, A.; Santo, M.R.d.E.; Menegazzo, L.M.; Moraes, J.C.S.; dos Santos, P.H. Effect of light curing modes on mechanical properties of direct and indirect composites. Acta Odontol. Scand. 2013, 71, 697-702. [CrossRef] [PubMed]

14. Akiba, S.; Takamizawa, T.; Tsujimoto, A.; Moritake, N.; Ishii, R.; Barkmeier, W.W.; Latta, M.A.; Miyazaki, M. Influence of different curing modes on flexural properties, fracture toughness, and wear behavior of dual-cure provisional resin-based composites. Dent. Mater. J. 2019, 38, 728-737. [CrossRef] [PubMed]

15. Ajaj, R.; Yousef, M.; Abo El Naga, A. Effect of different curing modes on the degree of conversion and the microhardness of different composite restorations. Dent Hypotheses 2015, 6, 109. [CrossRef]

16. Khaksaran, N.K.; Kashi, T.J.; Rakhshan, V.; Zeynolabedin, Z.S.; Bagheri, H. Kinetics of pulpal temperature rise during light curing of 6 bonding agents from different generations, using light emitting diode and quartz-tungsten-halogen units: An in-vitro simulation. Dent. Res. J. (Isfahan) 2015, 12, 173-180.

17. Jo, S.-A.; Lee, C.-H.; Kim, M.-J.; Ferracane, J.; Lee, I.-B. Effect of pulse-width-modulated LED light on the temperature change of composite in tooth cavities. Dent. Mater. 2019, 35, 554-563. [CrossRef]

18. Braga, S.; Oliveira, L.; Ribeiro, M.; Vilela, A.; da Silva, G.; Price, R.; Soares, C. Effect of Simulated Pulpal Microcirculation on Temperature When Light Curing Bulk Fill Composites. Oper. Dent. 2019, 44, 289-301. [CrossRef]

19. Kim, R.J.-Y.; Lee, I.-B.; Yoo, J.-Y.; Park, S.-J.; Kim, S.-Y.; Yi, Y.-A.; Hwang, J.-Y.; Seo, D.-G. Real-Time Analysis of Temperature Changes in Composite Increments and Pulp Chamber during Photopolymerization. BioMed Res. Int. 2015, 2015, 1-6. [CrossRef]

20. Hubbezoglu, I.; Dogan, A.; Dogan, O.M.; Bolayir, G.; Bek, B. Effects of Light Curing Modes and Resin Composites on Temperature Rise under Human Dentin: An in vitro Study. Dent. Mater. J. 2008, 27, 581-589. [CrossRef]

21. Schneider, L.F.; Consani, S.; Correr-Sobrinho, L.; Correr, A.B.; Sinhoreti, M.A. Halogen and LED light curing of composite: Temperature increase and Knoop hardness. Clin. Oral Investig. 2006, 10, 66-71. [CrossRef] [PubMed]

22. Guenka Palma-Dibb, R.; Savaris, C.; Alexandra Chinelatti, M.; Augusto de Lima, F.; Bachmann, L.; Jendiroba Faraoni, J. Composite Photopolymerization: Temperature Increase According to Light Source and Dentin Thickness. JDOI 2016, 1, 11-19. [CrossRef]

23. Santini, A.; Watterson, C.; Miletic, V. Temperature Rise Within the Pulp Chamber During Composite Resin Polymerisation Using Three Different Light Sources. TODENTJ 2008, 2, 137-141. [CrossRef] [PubMed]

24. Bağiş, B.; Bagis, Y.; Ertas, E.; Ustaomer, S. Comparison of the Heat Generation of Light Curing Units. J. Contemp. Dent. Pract. 2008, 9, 65-72. [CrossRef]

25. Pieniak, D.; Niewczas, A.M.; Walczak, M.; Zamościńska, J. Influence of photopolymerization parameters on the mechanical properties of polymer-ceramic composites applied in the conservative dentistry. Acta Bioeng. Biomech. 2014, 16, 29-35. [CrossRef]

26. Da Silva, E.M.; Poskus, L.T.; Guimarães, J.G.A. Influence of Light-polymerization Modes on the Degree of Conversion and Mechanical Properties of Resin Composites: A Comparative Analysis Between a Hybrid and a Nanofilled Composite. Oper. Dent. 2008, 33, 287-293. [CrossRef]

27. Witzel, M.F.; Calheiros, F.C.; Gonçalves, F.; Kawano, Y.; Braga, R.R. Influence of photoactivation method on conversion, mechanical properties, degradation in ethanol and contraction stress of resin-based materials. J. Dent. 2005, 33, 773-779. [CrossRef]

28. Calheiros, F.; Kawano, Y.; Stansbury, J.; Braga, R. Influence of radiant exposure on contraction stress, degree of conversion and mechanical properties of resin composites. Dent. Mater. 2006, 22, 799-803. [CrossRef] 